\title{
Pengaruh Harga Saham, Return Saham, Volume Perdagangan, dan Risiko Return Saham Terhadap Bid Ask Spread pada Perusahaan di Indeks LQ45
}

\author{
Fita Krisdayanti ${ }^{1}$, Tuti Zakiyah ${ }^{2}$ \\ 1,2 Sekolah Tinggi Ilmu Ekonomi Putra Bangsa \\ Email: fita.tomorrow@gmail.com ${ }^{1}$
}

\section{ARTICLE INFO}

Article History:

Received: April 17th 2021

Accepted: April 26 2021

Published: May $6^{\text {th }} 2021$

Keywords:

Bid Ask Spread, Stock Price,

Stock Return, Trading

Volume, Stock Return Risk

\begin{abstract}
The purpose of this study was to determine the effect of Stock Price, Stock Return, Trade Volume and Stock Return Risk partially or simultaneously on the bid ask spread of the LQ45 index companies 2019. The data source used in this study was daily secondary data. The population used in this study are companies listed in the 2019 LQ45 index, totaling 45 companies. The sampling technique used purposive sampling method which resulted in a total sample size of 37 companies and 245 days, thus forming a panel data of 9,065 samples. The analysis technique used is the Fixed Effect Model panel data regression analysis with the help of eviews 10 software application. The results show that: 1) stock prices have a significant effect on the bid ask spread, 2) stock returns have no significant effect on the bid ask spread, 3) volume stock trading has a significant effect on the bid ask spread, 4) the risk of stock return has a significant effect on the bid ask spread, 5) the stock price, stock return, trading volume, and the risk of stock return have a significant effect on the bid ask spread.
\end{abstract}

\section{Pendahuluan}

Bursa Efek Indonesia (BEI) merupakan pasar modal dan telah membuat pengelompokan terhadap saham-saham yang terdaftar pada Bursa Efek Indonesia (BEI) ke dalam beberapa indeks saham, salah satunya adalah LQ45. Sesuai dengan namanya, Indeks Liquid (LQ) 45, merupakan indeks yang terdiri dari 45 perusahaan yang memiliki tingkat likuiditas tertinggi pada periode tertentu. Saham LQ45 merupakan saham-saham yang aktif diperdagangkan, sehingga peka pada perubahan harga permintaan dan perubahan harga penawaran (Rahardjo, 2004).

Menurut Tandelilin (2010: 87), insentisitas transaksi setiap sekuritas di pasar modal berbedabeda. Sebagian sekuritas memiliki frekuensi yang sangat tinggi dan aktif diperdagangkan di pasar modal, namun sebagian lagi menunjukkan frekuensi transaksi yang relatif sedikit dan cenderung bersifat pasif. 
Beberapa saham yang menjadi konstituen indeks LQ45 mengalami penguatan luar biasa pada pekan-pekan terakhir sebelum penutupan perdagangan saham pada akhir tahun 2019. Salah satu penyebab melesatnya saham-saham LQ-45 dan saham-saham berkapitalisasi pasar besar (big capitalization/big cap) dikarenakan masuknya dana-dana asing (foreign investor) ke pasar saham dalam negeri.

Bursa Efek Indonesia (BEI) melaporkan pertumbuhan positif atas jumlah investor di pasar modal Indonesia. Per Mei tahun 2019, jumlah investor pasar modal Indonesia sebesar 1,9 juta. Tingginya angka tersebut menandakan semakin besarnya minat masyarakat untuk menabung saham, sebagaimana yang selama ini dikampanyekan BEI.

Otoritas Jasa Keuangan (OJK) menilai kondisi pasar modal Indonesia pada tahun 2019 cukup positif di tengah perkembangan global yang sulit. Aktivitas perdagangan Pasar Modal Indonesia juga mengalami peningkatan yang tercermin dari kenaikan rata-rata frekuensi perdagangan yang tumbuh

Besarnya bid-ask spread berpengaruh pada pertimbangan untuk mendapatkan keuntungan optimal dengan mengurangi risiko sampai serendah-rendahnya. Apabila seorang investor memprediksikan, bahwa saham perusahaan yang dibelinya menguntungkan maka investor akan menahan saham dalam jangka waktu yang lebih lama.

Salah satu elemen penting dalam biaya transaksi adalah spread antara harga bid dan harga ask. Biaya ini berhubungan dengan keinginan dealer untuk memperdagangkan saham mereka. Harga bid adalah harga dimana dealer bersedia untuk membeli suatu sekuritas, sedangkan harga ask adalah harga dimana dealer bersedia untuk menjual suatu sekuritas. Perbedaan antara harga bid dan harga ask ini adalah spread. Jadi bid-ask spread merupakan selisih antara harga jual dan harga beli.

Dalam membuat keputusan investasinya, seorang investor yang rasional akan mempertimbangkan risiko dan tingkat keuntungan yang diharapkan. Untuk itu investor seharusnya melakukan analisis sebelum menentukan saham yang akan mereka beli. Dalam melakukan analisis, investor memerlukan informasi. Adanya informasi yang dipublikasikan akan merubah keyakinan para investor yang dilihat dari reaksi pasar. Salah satu reaksi pasar tersebut adalah volume perdagangan saham. Volume perdagangan saham merupakan ukuran besarnya saham tertentu yang diperdagangkan, mengindikasikan kemudahan dalam memperdagangkan saham tersebut. Besarnya variabel volume perdagangan diketahui dengan mengamati kegiatan perdagangan yang dapat dilihat melalui indikator aktivitas perdagangan Trading Volume Activity (TVA). Volume perdagangan merupakan volume perdagangan harian saham selama periode penelitian.

\section{Kajian Teori dan Telaah Literatur}

\section{Teori Spread}

Teori spread menyatakan bahwa nilai bid-ask spread ditentukan oleh dealer atau broker yang secara bersama-sama melakukan transaksi atas suatu saham. Di Bursa Efek Indonesia (BEI) menggunakan pendekatan market spread karena dealer berperan ganda yaitu sebagai dealer dan sebagai broker. Hal ini disebabkan karena Bursa Efek Indonesia bersifat competitive order matching market atau order drive market system. Dengan sistem ini investor hanya 
diperbolehkan untuk menyerahkan order transaksi melalui broker atau dengan kata lain seorang investor tidak dapat melakukan transaksi sendiri di lantai bursa. (Paramita \& Yulianto, 2014).

Berdasarkan Undang-Undang Pasar Modal No. 8 tahun 1995 dan Peraturan Pemerintah RI No. 45 tahun 1995, perusahaan efek adalah pihak yang melaksanakan kegiatan adalah Penjamin Emisi Efek (PPE), Perantara Pedagang Efek (PPE) dan Manajer Investasi (MI). Dengan demikian maka penelitian tentang spread lebih dihubungkan secara erat dengan PPE (dealer) daripada dengan perantara investasi (broker). Dealer adalah pihak yang dalam pelaksanaan transaksi jual beli sekuritas atau saham, mempunyai andil yang besar dalam pasar modal. Banyak hal yang telah dealer lakukan agar proses transaksi dapat berjalan dengan baik dan lancar yaitu pada saat investor yang berkeinginan untuk membeli atau menjual saham sesuai dengan harga dan jumlah yang diinginkan namun keinginan tersebut terealisir dalam waktu yang cukup lama, maka dealer akan berusaha mengatasi ketidaksamaan waktu tersebut terhadap order yang dihadapi investor sebagai perantara perdagangan sekuritas yang dilakukan individu secara tidak langsung. (Ambarwati, 2008).

\section{Signalling Theory}

Asumsi dari teori sinyal, bahwa manajemen mempunyai informasi yang akurat tentang nilai perusahaan yang tidak diketahui oleh investor luar mengenai faktor-faktor yang mempengaruhi nilai perusahaan dan manajemen selalu berusaha meningkatkan keuntungan.

Signaling theory menjelaskan tentang bagaimana para investor memiliki informasi yang sama tentang prospek perusahaan. Hal tersebut akan terlihat jika manajemen tidak secara penuh menyampaikan semua semua informasi yang diperolehnya yang dapat mempengaruhi perusahaan terhadap pasar, maka umumnya pasar akan merespon informasi tersebut sebagai suatu sinyal terhadap adanya kejadian tertentu yang dapat mempengaruhi nilai perusahaan yang tercermin dari perubahan harga saham (Jogiyanto, 2000).

Pihak manajemen yang menyampaikan informasi ke pasar maka pasar akan merespon informasi tersebut sebagai suatu sinyal bahwa adanya peristiwa tertentu yang mempengaruhi nilai perusahaan, sehingga adanya pengumuman right issue atau penambahan saham baru juga akan direspon oleh pasar sebagai suatu sinyal yang akan berpengaruh terhadap nilai saham perusahaan dan aktivitas perdagangan saham (Purwanto, 2004).

\section{Indeks LQ45}

Indeks LQ45 adalah indeks yang terdiri dari 45 saham perusahaan go public yang dipilih berdasarkan pertimbangan tingkat likuiditas yang tinggi dan kapitalisasi pasar yang besar serta lolos seleksi dengan beberapa kriteria pemilihan. Indeks LQ45 diluncurkan pada bulan Februari 1997. Sejak diluncurkan pada bulan Februari 1997 ukuran utama likuiditas transaksi adalah nilai transaksi di pasar reguler. Sesuai dengan perkembangan pasar, dan untuk lebih mempertajam kriteria likuiditas, maka sejak reviews bulan Januari 2005, jumlah perdagangan dan frekuensi transaksi dimasukkan sebagai ukuran likuiditas. Nilai pasar agregat dari saham-saham tersebut meliputi sekitar lebih dari $72 \%$ dari total kapitalisasi pasar di Bursa 
Efek Indonesia. Nilai agregat ini meliputi sekitar 72,5\% dari total transaksi di pasar regular. Dengan demikian indeks LQ-45 ini memberikan gambaran yang akurat akan perubahan nilai pasar dari seluruh saham yang aktif diperdagangkan di Bursa Efek Indonesia (BEI) (Fakhuddin dan Hardianto, 2001:203). Untuk dapat masuk dalam Indeks LQ45, suatu saham harus memenuhi kriteria tertentu melewati seleksi utama, sebagai berikut:

1. Masuk dalam urutan 60 terbesar dari total transaksi saham di pasar reguler (rata-rata nilai transaksi selama 12 bulan terakhir).

2. Urutan berdasarkan kapitalisasi pasar (rata-rata nilai kapitalisasi pasar selama 12 bulan terakhir),

3. Telah tercatat di BEI selama paling sedikit 3 bulan.

Selain melihat kriteria likuiditas dan kapitalisasi pasar, indeks LQ45 juga melihat keadaan kondisi keuangan dan prospek pertumbuhan perusahaan. Bursa efek secara rutin memantau perkembangan kinerja masing-masing ke-45 saham yang masuk dalam perhitungan Indeks LQ45. Indeks LQ-45 ini akan ditinjau ulang setiap 3 bulan, dilakukan review pergerakan ranking saham-saham yang akan digunakan dalam perhitungan indeks LQ-45. Penggantian saham dilakukan setiap enam bulan sekali, yaitu pada awal bulan Februari dan Agustus. Apabila terdapat saham yang tidak memenuhi kriteria seleksi, maka saham tersebut dikeluarkan dari perhitungan indeks dan diganti dengan saham lain yang memenuhi kriteria.

\section{Bid Ask Spread}

Salah satu cara untuk mendeteksi asimetri informasi adalah dengan perhitungan bid ask. Bidask spread merupakan selisih antara bid price dengan ask price. Bid price adalah harga tertinggi yang ditawarkan oleh dealer atau harga dimana spesialis atau dealer menawarkan untuk membeli saham. Sedangkan ask price adalah harga terendah dimana dealer bersedia untuk menjual saham (Dewi \& Kartika, 2015).

Bid-ask spread ditentukan oleh dealer. Bid-ask spread yang terlalu tinggi akan menguntungkan dealer, namun bid-ask spread yang terlalu tinggi akan mengakibatkan saham tersebut menjadi kurang aktif diperdagangkan. Bid-ask spread yang terlalu rendah akan merugikan dealer, namun bid-ask spread yang terlalu rendah akan mengakibatkan saham tersebut menjadi lebih aktif diperdagangkan. Oleh karena itu dealer akan berusaha untuk menentukan tingkat bidask spread yang optimal, yaitu tingkat bid-ask spread yang tidak merugikan dealer dan membuat saham tersebut aktif diperdagangkan. (Supardi, 2010).

Menurut Aprilia (2015), bid ask spread adalah perbedaan antara harga yang dikutip (baik oleh pembuat pasar tunggal atau dalam buku pesanan terbatas) untuk sebuah penjualan langsung (penawaran) dan pembelian langsung tawaran) untuk saham, kontrak berjangka, opsi, atau pasangan mata uang. Ukuran bid-ask spread dalam sekuritas adalah salah satu ukuran likuiditas pasar dan ukuran biaya transaksi. Jika spread 0 maka itu adalah aset tanpa gesekan. Jenis bid-ask spread yang paling sederhana adalah kuotasi spread. Spread ini diambil langsung dari kuotasi, yaitu harga yang dipasang. Menggunakan kuotasi, spread ini adalah selisih antara harga permintaan terendah (harga terendah di mana seseorang akan menjual) dan harga penawaran tertinggi (harga tertinggi di mana seseorang akan membeli).

\section{Harga Saham}

Harga saham adalah harga yang ditetapkan dari suatu saham pada saat pasar saham sedang berlangsung dengan mempertimbangkan permintaan dan penawaran dari saham yang 
dimaksud (Jogiyanto, 2015). Perubahan harga saham ditentukan berdasarkan penilaian investor terhadap perusahaan. Apabila perusahaan dipandang memiliki masa depan yang baik, dan diperkirakan akan berkembang pesat, maka investor tersebut memberikan penilaian yang tinggi terhadap saham perusahaan yang sedang dipertukarkan, demikian pula sebaliknya (Aprilia, 2015). Harga saham yang senantiasa memberikan return yang tinggi mengidentifikasikan bahwa saham tersebut disukai oleh investor, sehingga dealer (perantara pedagang efek) tidak perlu memegang saham tersebut terlalu lama sehingga menurunkan biaya pemilikan saham yang berarti mempersempit bid-ask spread (Paramita \& Yulianto, 2014). Harga saham adalah harga penutupan per lembar saham pada saat tertentu yang ditentukan oleh pelaku pasar dan oleh permintaan dan penawaran saham yang bersangkutan di pasar modal (Rahardjo, 2004).

Harga saham adalah harga suatu saham yang terjadi di pasar bursa pada saat tertentu yang ditentukan oleh pe laku pasar dan ditentukan oleh permintaan dan penawaran saham yang bersangkutan di pasar modal (Jogiyanto, 2008). Harga saham menjadi salah satu indikator pengelolaan perusahaan. Keberhasilan dalam menghasilkan keuntungan akan memberikan kepuasan bagi investor yang rasional. Harga saham yang cukup tinggi akan memberikan keuntungan, yaitu berupa capital gain dan citra yang lebih baik bagi perusahaan sehingga memudahkan bagi manajemen untuk mendapatkan dana dari luar perusahaan (Perdana dan Kristanti, 2014). Ketika harga saham tinggi, berarti saham aktif diperdagangkan, sehingga dealer tidak akan menyimpan saham tersebut dalam jangka waktu terlalu lama. Hal ini akan berdampak pada tingkat bid-ask spread dan menurunnya biaya kepemilikan yang pada akhirnya menyebabkan semakin tingginya harga saham dan semakin kecilnya bid-ask spread (Wahyuliantini dan Suarjaya, 2015).

Jenis-Jenis Harga Saham Irwansyah (2013), mengatakan harga saham dibedakan menjadi 3 jenis, yaitu:

\section{Harga Nominal}

Harga yang tercantum dalam sertifikat yang diterapkan oleh emiten untuk menilai setiap lembar saham yang dikeluarkan. Besarnya harga nominal memberikan arti penting saham karena deviden minimal biasanya ditetapkan berdasarkan nilai nominal.

\section{Harga Perdana}

Harga perdana merupakan harga pada waktu harga saham tesebut dicatat di busa efek. Harga saham pada pasar perdana biasanya ditetapkan oleh penjamin emisi (underwriter) dan emiten. Dengan demikian akan diketahui berapa harga saham emiten itu akan dijual kepada masyarakat.

\section{Harga Pasar}

Harga pasar adalah harga jual investor yang satu dengan investor lain. Harga ini terjadi setelah saham tersebut dicatatkan di bursa. Transaksi disini tidak lagi melibatkan emiten dari penjamin emisi, harga ini yang disebut sebagai harga pasar sekunder dan harga inilah yang benar-benar mewakili harga perusahaan penerbitnya, karena pada transaksi di pasar sekunder kecil sekali terjadi negosiasi harga investor dengan perusahaan penerbit. Harga setiap hari diumumkan di surat kabar atau media lain.

\section{Return Saham}

Salah satu tujuan investor berinvestasi adalah untuk mendapatkan return. Tanpa adanya tingkat keuntungan yang dinikmati dari suatu investasi, tentunya investor tidak akan melakukan investasi. Jadi semua investasi mempunyai tujuan utama untuk mendapatkan return. Van Horn (2009: 98), mengatakan "return is an income received on an investment plus any change in market price, usually expressed as a percentage of the beginning market price of the investment". Gitman (2013 : 311), mendefinisikan return sebagai "the total gain or loss 
experienced on an investment over a given period". Rusliati dan Farida (2010) mengatakan "return merupakan salah satu hal penting yang perlu dipertimbangkan dan memaksimalkannya selalu menjadi tujuan utama dari proses investasi". Ginting dan Henny (2014) mengatakan "return adalah keuntungan yang diperoleh sebagai akibat melakukan investasi". Tujuan utama para investor menanamkan sahamnya adalah untuk memperoleh keuntungan yang semaksimal mungkin dengan resiko kerugian seminim mungkin. Return yang diterima oleh investor dari saham dapat berupa deviden yang diterima secara periodik, atau dari capital gain.

Return saham memungkinkan seorang investor untuk membandingkan keuntungan aktual ataupun keuntungan yang diharapkan dan disediakan oleh berbagai saham pada tingkatan pengembalian yang diinginkan. Menurut Jogiyanto (2015) merupakan return yang telah terjadi. Return realisasi dapat di ukur dengan menggunakan banyak metode salah satunya adalah return total yang merupakan return secara keseluruhan dari suatu investasi dalam suatu periode tertentu yang terdiri dari capital gain dan yield (Chotimah \& Amanah, 2013). Return total terdiri dari capital gain dan yield. Capital gain/loss merupakan selisih dari harga investasi sekarang relatif dengan harga periode yang lalu. Sedangkan yield adalah merupakan prosentase penerimaan kas periodik terhadap harga investasi periode tertentu dari suatu investasi (Chotimah \& Amanah, 2013).

\section{Volume Perdagangan Saham}

Volume perdagangan adalah jumlah saham atau surat berharga yang diperdagangkan di pasar modal selama periode yang telah ditentukan. (Paramita \& Yulianto, 2014). Volume perdagangan saham merupakan rasio antara jumlah lembar saham yang diperdagangkan pada waktu tertentu terhadap jumlah saham yang beredar pada waktu tertentu. Untuk membuat keputusan investasinya, seorang investor yang rasional akan mempertimbangkan risiko dan tingkat keuntungan yang diharapkan (Napitupulu \& Syahyuan, 2013). Volume perdagangan diartikan sebagai besarnya aktivitas jumlah lembar sham yang diperdagangkan. Investor akan melihat aktivitas ini untuk menilai informasi dari saham tersebut. Volume perdagangan yang besar menunjukkan bahwa saham tersebut digemari oleh para investor dan cepat diperdagangkan. Sebaliknya, volume perdagangan yang kecil menunjukkan saham tersebut kurang likuid sehingga investor cenderung kurang menyukai melakukan perdagangan pada saham tersebut (Aprilia, 2015).

Menurut Napitupulu (2013), volume perdagangan merupakan bagian dari analisis teknikan. Volume perdagangan yang tinggi dianggap sejalan dengan kenaikan harga saham. Volume perdagangan saham merupakan rasio antara jumlah lembar saham yang diperdagangkan pada waktu tertentu terhadap jumlah saham yang beredar pada waktu tertentu. Menurut Ambarwati (2008), volume perdagangan diartikan sebagai jumlah lembar saham yang di perdagangkan pada hari tertentu. Perdagangan suatu saham yang aktif, yaitu dengan volume perdagangan yang besar, menunjukan bahwa saham tersebut digemari oleh para investor yang berarti saham tersebut cepat diperdagangkan. Ada kemungkinan para pelaku pasar akan mengubah posisi kepemilikan sahamnya pada saat perdagangan saham semakin tinggi atau para pelaku pasar tidak perlu memegang saham dalam jumlah terlalu lama. Dengan demikian semakin aktif perdagangan suatu saham atau semakin besar volume perdagangan suatu saham, maka semakin rendah biaya pemilikan saham tersebut yang berarti akan mempersempit bid ask spread saham tersebut.

\section{Risiko Return Saham}

Risk of Return adalah varian dari return saham yang dianggap berpengaruh positif terhadap bid-ask spread. Apabila volatilitas harga saham tinggi, pedagang lebih memiliki 
peluang untuk memperoleh keuntungan (gain). Hal ini menyebabkan broker atau dealer memperbesar keuntungan sebagai kompensasi atas risiko kerugian dengan meningkatkan spread nya. Variabilitas return saham mewakili risiko yang dihadapi broker atau dealer karena memegang suatu saham. Semakin besar risiko suatu saham, maka broker atau dealer berusaha menutupinya dengan spread yang lebih besar. Varian return saham juga merupakan risiko saham yang dapat mempengaruhi besar kecilnya bid-ask spread saham. Varian return saham mewakili risiko saham.

Risiko dalam investasi saham biasa juga harus dipertimbangkan oleh investor. Return dan risiko mempunyai hubungan yang positif, semakin besar risiko yang harus ditanggung, semakin besar return yang harus dikompensasikan. Risiko merupakan besarnya penyimpangan antara tingkat pengembalian yang diharapkan (expected return) dengan tingkat pengembalian aktual (actual return). Apabila risiko dinyatakan sebagai seberapa jauh hasil yang diperoleh dapat menyimpang dari hasil yang diharapkan, maka digunakan ukuran penyebaran. Alat statistik yang digunakan sebagai ukuran penyebaran tersebut adalah varians atau deviasi standar. Semakin besar nilainya, berarti semakin besar penyimpangannya (berarti risiko semakin tinggi).

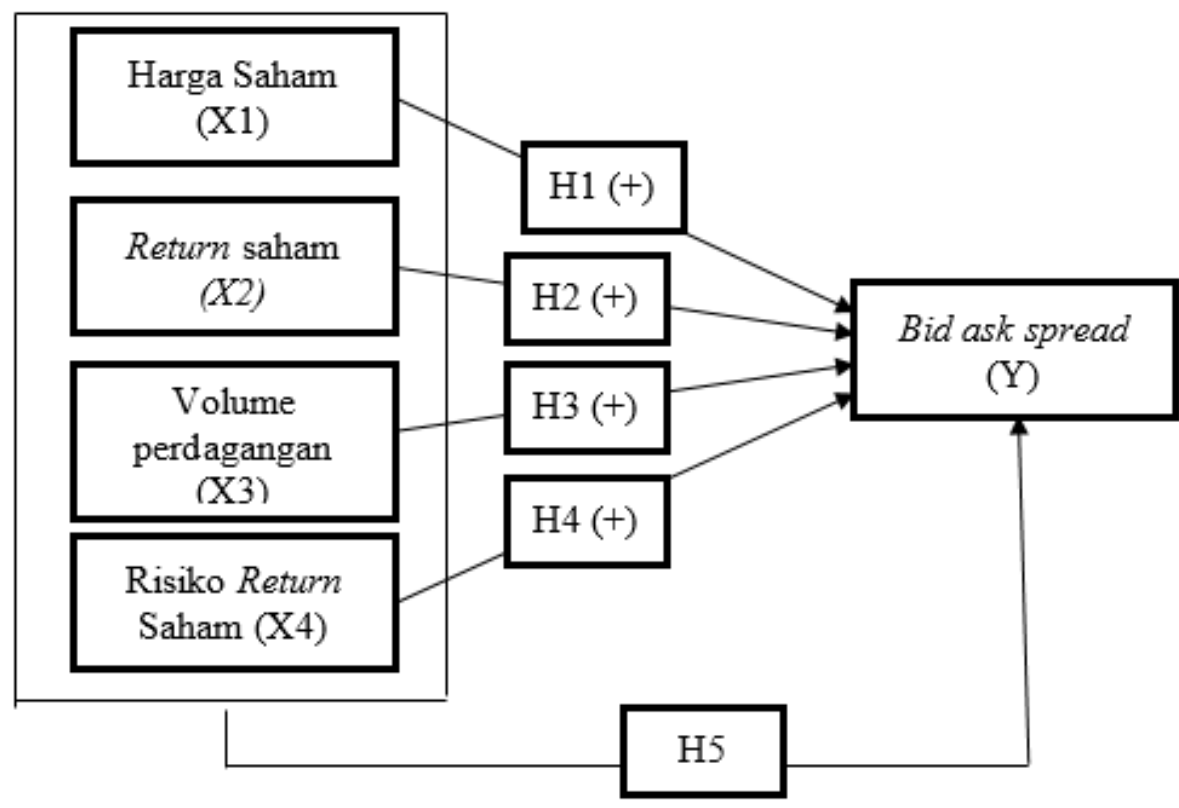

Gambar 1. Kerangka Pemikiran Teoritis

Harga saham, return saham, volume perdagangan saham, dan risiko return saham saling berkaitan sebagai indikator untuk mengetahui pengaruh besar kecilnya bid ask spread. Dari uraian di atas dapat dirumuskan sebagai berikut:

$\mathbf{H}_{\mathbf{1}}$ : Harga saham memiliki pengaruh positif terhadap bid ask spread

$\mathbf{H}_{2}$ : Return saham memiliki pengaruh positif terhadap bis ask spread

$\mathbf{H}_{3}$ : Volume perdagangan saham memiliki pengaruh positif terhadap bid ask spread

$\mathbf{H}_{4}$ : Risiko Return Saham memiliki pengaruh positif terhadap bid ask spread

$\mathbf{H}_{5}$ : Harga Saham, Return Saham, Volume Perdagangan, dan Risiko Return Saham secara simultan berpengaruh terhadap bid ask spread 


\section{Metode Penelitian}

\section{Populasi dan Sampel}

Populasi yang digunakan dalam penelitian ini adalah perusahaan yang terdaftar di Indeks LQ45 di Bursa Efek Indonesia (BEI) tahun 2019.

Teknik pengambilan sampel yang digunakan dalam penelitian ini adalah purposive sampling. Purposive sampling adalah penentuan sampel dengan pertimbangan atau kriteria tertentu. Kriterianya adalah saham terdaftar pada indeks LQ45 secara konsisten selama tahun 2019. Kriterianya adalah sebagai berikut :

1. Perusahaan terdaftar pada indeks LQ45 secarakonsisten selama tahun 2019.

2. Saham yang tidak melakukan stock split.

3. Saham yang memiliki hari bursa sebanyak 245 hari.

Berdasarkan kriteria dalam penentuan sampel, terpilih 9.065 sampel dalam penelitian ini yang terdiri dari 37 perusahaan LQ45 dengan hari bursa selama 245 hari.

\section{Metode Pengumpulan Data}

Metode pengumpulan data dalam penelitian ini menggunakan dokumentasi data sekunder yaitu jumlah saham beredar dalam bentuk ringkasan yang dipublikasikan oleh yahoo.finance untuk tahun 2019.

\section{Populasi dan Sampel}

\section{Variabel Independen (Variabel Bebas)}

1. Harga saham

Perhitungan harga saham dalam penelitian ini menggunakan harga penutupan atau closing price masing-masing saham i pada penutupan bursa hari ke-t.

2. Return Saham

Return saham didefinisikan sebagai perubahan relatif harga saham dari periode sebelumnya (Jogiyanto, 2000) dalam Ambarwati (2008) yang dirumuskan:

$\mathrm{R}_{\mathrm{t}}=\frac{\left(\mathrm{P}_{\mathrm{t}}-\mathrm{P}_{\mathrm{t}-1}\right)}{\mathrm{P}_{\mathrm{t}-1}}$

Keterangan :

Rt : Return Saham

$\mathrm{Pt} \quad$ : Harga penutupan saham hari ke $(\mathrm{t})$

Pt-1 : Harga penutupan saham hari ke (t-1)

3. Volume Perdagangan Saham

Volume perdagangan saham (Vt) didefinisikan sebagai jumlah lembar saham yang diperdagangkan pada hari ke-t.

4. Risiko return saham

Risiko return realisasi menurut (Jogiyanto, 2003:131) di rumuskan sebagai berikut:

$$
\mathrm{RS}=\frac{\sqrt{\sum_{\mathrm{i}-1}^{\mathrm{n}}\left(\mathrm{xi}-\mathrm{x}^{2}\right.}}{\mathrm{n}-1}
$$

Keterangan :

RS : Return Saham

Xi : Nilai Saham ke i

$X \quad$ : Nilai Rata-Rata Saham

$\mathrm{N} \quad$ : Jumlah Observasi 


\section{Variabel Dependen (Variabel Terikat)}

Bid-ask spread merupakan biaya yang dikeluarkan dalam mekanisme perdagangan saham yang dihitung dengan mempergunakan rumus berikut:

BAS $=\frac{\left(\mathrm{P}_{\mathrm{a}}-\mathrm{P}_{\mathrm{b}}\right)}{\left(\mathrm{P}_{\mathrm{a}}+\mathrm{P}_{\mathrm{b}}\right) / 2}$

Keterangan :

BAS : Bid Ask Spread

$\mathrm{Pa} \quad$ : Price Ask

$\mathrm{Pb}$ : Price Bid

\section{Instrumen Penelitian}

Penelitian ini dilakukan dengan pengujian statistik untuk mengetahui variabel mempunyai pengaruh yang signifikan terhadap bid ask spread.

\section{Metode Analisis Data}

Pada penelitian ini menggunakan Microsoft Office Excel dan Eviews 10 untuk mengolah data dan pengujian hipotesis. Pengolahan dan perhitungan data sekunder untuk variabel bebas diolah dan dihitung menggunkan Microsoft Office Excel. Sementara pengolahan data sekunder untuk variabel terikat dan estimasi regresi data panel untuk menguji hipotesis menggunkan Eviews 10.

\section{Hasil dan Pembahasan}

\section{Estimasi Model Regresi Data Panel}

Estimasi model regresi data panel akan diduga menggunakan tiga metode yang ada dalam regresi data panel, yaitu :

a. Common Effect

\begin{tabular}{lllll} 
Variable & Coefficient & Std. Error & t-Statistic & Prob. \\
\hline \hline C & -0.021843 & 0.003857 & -5.662996 & 0.0000 \\
HS & 0.004396 & 0.000203 & 21.63672 & 0.0000 \\
RS & -0.046893 & 0.007388 & -6.346717 & 0.0000 \\
VOL_P & -0.002541 & 0.000167 & -15.19177 & 0.0000 \\
RISK_RS & $-3.94 \mathrm{E}-05$ & $1.08 \mathrm{E}-06$ & -36.63138 & 0.0000 \\
\hline \hline
\end{tabular}

b. Fixed Effect

\begin{tabular}{lllll} 
Variable & Coefficient & Std. Error & t-Statistic & Prob. \\
\hline \hline C & 0.011474 & 0.008270 & 1.387383 & 0.1654 \\
HS & 0.013721 & 0.000916 & 14.98325 & 0.0000 \\
RS & -0.004810 & 0.005426 & -0.886522 & 0.3754 \\
VOL_P & -0.009270 & 0.000186 & -49.72973 & 0.0000 \\
RISK_RS & $-4.47 E-05$ & $1.01 E-06$ & -44.11019 & 0.0000 \\
\hline \hline
\end{tabular}


c. Random Effect

\begin{tabular}{lllll} 
Variable & Coefficient & Std. Error & t-Statistic & Prob. \\
\hline \hline C & 0.097832 & 0.007197 & 13.59365 & 0.0000 \\
HS & 0.005384 & 0.000715 & 7.527877 & 0.0000 \\
RS & -0.011759 & 0.005932 & -1.982072 & 0.0475 \\
VOL_P & -0.010359 & 0.000208 & -49.71082 & 0.0000 \\
RISK_RS & $-3.57 \mathrm{E}-05$ & $1.00 \mathrm{E}-06$ & -35.58228 & 0.0000 \\
\hline \hline
\end{tabular}

\section{Pemilihan Estimasi Model Regresi Data Panel}

a. Uji Chow bertujuan untuk mengetahui pilihan model yang lebih baik digunakan antara common effect dan fixed effect.

Redundant Fixed Effects Tests

Equation: Untitled

Test cross-section fixed effects

\begin{tabular}{llll}
\hline \hline Effects Test & Statistic & d.f. & Prob. \\
\hline \hline $\begin{array}{l}\text { Cross-section F } \\
\text { Cross-section }\end{array}$ & 146.714095 & $(36,9024)$ & 0.0000 \\
$\begin{array}{l}\text { Chi-square } \\
4\end{array}$ & 4176.888054 & 36 & 0.0000 \\
\hline \hline
\end{tabular}

Berdasarkan tabel di atas, diperoleh nilai p-value (prob) pada cross-secction sebesar 0,0000 dan chi-square 0,0000 sehingga $<\alpha=0,05$ maka $\mathrm{H}_{0}$ ditolak yang artinya model fixed effect lebih baik digunakan daripada model random effect.

b. Uji Hausman bertujuan untuk mengetahui pilihan model yang lebih baik digunakan antara fixed effect dan random effect.

Correlated Random Effects - Hausman Test

Equation: Untitled

Test cross-section random effects

Test Summary Chi-Sq. Statistic Chi-Sq. d.f. Prob.

Cross-section random $164.349201 \quad 4 \quad 0.0000$

Berdasarkan tabel diatas, diperoleh nilai p-value (prob) sebesar 0,0000 sehingga $<a$ = 0,05 maka $\mathrm{H}_{0}$ ditolak yang artinya model fixed effect lebih baik digunakan daripada model random effect.

c. Uji Langrange Multiplierbertujuan untuk mengetahui pilihan model yang lebih baik digunakan antara common effect dan random effect. Berdasarkan Uji Chow dan Uji Hausman, dihasilkan model regresi data panel yang terpilih yaitu fixed effect model. Oleh karena itu, LM-Test tidak perlu dilakukan karena fixed effect model lebih baik. 


\section{Uji Hipotesis}

a. Uji Parsial (Uji t)

\begin{tabular}{lrrrr} 
Variable & Coefficient & Std. Error & t-Statistic & Prob. \\
\hline \hline C & 0.011474 & 0.008270 & 1.387383 & 0.1654 \\
HS & 0.013721 & 0.000916 & 14.98325 & 0.0000 \\
RS & -0.004810 & 0.005426 & -0.886522 & 0.3754 \\
VOL_P & -0.009270 & 0.000186 & -49.72973 & 0.0000 \\
RISK_RS & $-4.47 \mathrm{E}-05$ & $1.01 \mathrm{E}-06$ & -44.11019 & 0.0000 \\
\hline \hline
\end{tabular}

Berdasarkan tabel diatas, t-statistic variabel harga saham adalah 14.98325 lebih besar dari $t$ kritis (tabel) yaitu 1.960 dan p-value pada variabel harga saham sebesar 0.0000 lebih kecil dari $\alpha=0.05(5 \%)$ sehingga $\mathrm{H}_{0}$ ditolak dan $\mathrm{H}_{1}$ diterima. Hal ini menunjukkan bahwa harga saham memiliki pengaruh positif signifikan terhadap bid ask spread.

Berdasarkan tabel diatas, t-statistic variabel return saham adalah -0.886522 lebih kecil dari t kritis (tabel) yaitu 1.960 dan p-value pada variabel return saham sebesar 0.3754 lebih besar dari $\alpha=0.05(5 \%)$ sehingga $\mathrm{H}_{0}$ diterima dan $\mathrm{H}_{1}$ ditolak. Hal ini menunjukkan bahwa return saham tidak berpengaruh terhadap bid ask spread.

Berdasarkan tabel diatas, t-statistic variabel volume perdagangan saham adalah 49.72973 lebih besar dari t kritis (tabel) yaitu 1.960 dan p-value pada variabel volume perdagangan saham sebesar 0.0000 lebih kecil dari $\alpha=0.05(5 \%)$ sehingga $\mathrm{H}_{0}$ ditolak dan $\mathrm{H}_{1}$ diterima. Hal ini menunjukkan bahwa volume perdagangan saham memiliki pengaruh negatif signifikan terhadap bid ask spread.

Berdasarkan tabel diatas, t-statistic variabel risiko return saham adalah -44.11019 lebih besar dari t kritis (tabel) yaitu 1.960 dan p-value pada variabel risiko return saham sebesar 0.0000 lebih kecil dari a $=0.05(5 \%)$ sehingga $\mathrm{H}_{0}$ ditolak dan $\mathrm{H}_{1}$ diterima. Hal ini menunjukkan bahwa risiko return saham memiliki pengaruh negatif signifikan terhadap bid ask spread.

b. Uji signifikansi simultan uji $\mathrm{F}$

\begin{tabular}{cccc}
\hline & F-Statistic & Prob(F-Statistic) $/$ P-Value & Keterangan \\
\hline Nilai & 261.7843 & 0.000000 & signifikan \\
\hline Daerah Kritis $\mathrm{H}_{0}$ ditolak jika F-Statistic $>$ F tabel $(2.60)$ \\
\hline \multicolumn{3}{c}{ Daerah Kritis $\mathrm{H}_{0}$ ditolak jika P-Value $<\mathrm{a}=0.05$} \\
\hline
\end{tabular}

Berdasarkan tabel diatas, F-Statistic sebesar 261.7843 lebih besar dari f kritis (tabel) yaitu 2.60 dan p-value sebesar 0.000000 lebih kecil dari $\alpha=0.05(5 \%)$ sehingga $\mathrm{H}_{0}$ ditolak dan $\mathrm{H}_{5}$ diterima. Hal ini menunjukkan bahwa harga saham, return saham, volume perdagangan, dan risiko return saham secara simultan berpengaruh signifikan terhadap bid ask spread.

\section{Uji Kecocokan Model}

\begin{tabular}{lc}
\hline Koef. Determinasi & Nilai Koefisien \\
\hline R-squared & 0.537121 \\
Adjusted R-squared & 0.535069 \\
\hline
\end{tabular}


Berdasarkan tabel diatas, uji goodness of fit yang dilambangkan dengan nilai koefisien determinasi (adjusted R-square) sebesar 0.537121 atau $53.71 \%$. hal ini menunjukkan bahwa bid ask spread mampu dijelaskan oleh variabel independen dalam model regresi yaitu harga saham, return saham, volume perdagangan, dan risiko return saham sebesar $53.71 \%$, sedangkan sisanya $46.29 \%$ dijelaskan oleh variabel lain di luar model penelitian.

\section{Uji Asumsi Klasik}

Berdasarkan uji hipotesis yang telah dilakukan variabel independen yang terdiri dari harga saham, return saham, volme perdagangan dan risiko return saham menunjukkan arah pengaruh yang sesuai dengan hipotesis dan bersifat signifikan baik secara parsial maupun secara simultan. Menurut Gujaranti dan Porter (2012) pada contoh ilustratif estimasi regresi data panel, menyatakan bahwa "semua variabel yang menunjukkan tanda yang diharapkan dan semuanya secara individu maupun secara kolektif bersifat signifikan secara statistik sehingga dapat diasumsikan bahwa semua asumsi model regresi linear klasik terpenuhi". Berdasarkan kutipan tersebut, maka dapat disimpulkan bahwa uji asumsi klasik tidak perlu dilakukan pada model penelitian ini karena estimator telah mempunyai sifat tidak bias, linear dan mempunyai varian yang minimum atau memiliki karakteristik BLUE (Best Linear Unbiased Estimator).

\section{Pembahasan}

\section{Pengaruh Harga Saham Terhadap Bid Ask Spread}

Berdasarkan analisis regresi data panel yang telah dilakukan, variabel harga saham memiliki t-statistic 14.98325 lebih besar dari t kritis (tabel) yaitu 1.960 dan p-value pada variabel harga saham sebesar 0.0000 lebih kecil dari $\alpha=0.05(5 \%)$, sehingga harga saham memiliki pengaruh yang signifikan terhadap bid ask spread. Harga saham merupakan indikator keberhasilan pengelolaan perusahaan, dimana kekuatan pasar ditunjukkan dengan terjadinya transaksi perdagangan saham perusahaan di pasar modal. Harga saham yang senantiasa memberikan return yang tinggi mengindikasikan bahwa saham tersebut disukai oleh investor sehingga broker atau dealer (perantara pedagang efek) tidak perlu memegang saham tersebut terlalu lama sehingga menurunkan biaya pemilikan saham yang berarti mempersempit bid-ask spread saham tersebut. Perubahan harga saham ditentukan berdasarkan penilaian investor terhadap perusahaan. Apabila perusahaan dipandang memiliki masa depan yang baik, dan diperkirakan akan berkembang pesat, maka investor tersebut memberikan penilaian yang tinggi terhadap saham perusahaan yang sedang dipertukarkan, demikian pula sebaliknya (Aprilia, 2015). Hasil menunjukkan bahwa harga saham berpengaruh positif signifikan terhadap bid ask spread. Hasil penelitian ini sesuai dengan penelitian Leoni Bidara Rasyidi, Yunika Murdayanti (2013), Anak Agung Gede Suarjaya (2015), Agung Yulianto (2014) yang menyatakan bahwa harga saham bepengaruh signifikan.

Harga saham cenderung naik dalam tiap transaksinya, sehingga menghasilkan return saham yang tinggi, karena ketika harga saham tinggi, berarti saham aktif diperdagangkan, sehingga dealer tidak akan menyimpan saham tersebut dalam jangka waktu terlalu lama. Hal ini akan berdampak pada tingkat bid-ask spread dan menurunnya biaya kepemilikan yang pada akhirnya menyebabkan semakin tingginya harga saham dan semakin kecilnya bid-ask spread.

\section{Pengaruh Return Saham Terhadap Bid Ask Spread}

Berdasarkan analisis regresi data panel yang telah dilakukan, variabel return saham memiliki t-statistic -0.886522 lebih kecil dari t kritis (tabel) yaitu 1.960 dan p-value pada variabel return 
saham sebesar 0.3754 lebih besar dari $\mathrm{a}=0.05(5 \%)$ sehingga return saham berpengaruh negatif signifikan terhadap bid ask spread. Semakin tinggi return yang di dapat atas suatu investasi, hal ini menunjukkan bahwa saham tersebut aktif dalam perdagangan. Dealer sebagai pihak penghubung akan menurunkan biaya karena tidak menahan saham dalam waktu yang cukup lama dan akan menurunkan bid-ask spread (Ambarwati, 2008). Return yang tinggi mengindikasikan bahwa saham tersebut aktif diperdagangkan. Apabila suatu saham dapat dikatakan aktif dalam perdagangan, maka dealer tidak perlu waktu yang lama untuk menyimpan saham yang akan diperdagangkan (Nany, 2003). Dengan demikian biaya untuk kepemilikan pada akhirnya akan menurun, hal ini akan sejalan dengan menurunnya tingkat bid-ask spread. Hasil penelitian ini sesuai dengan penelitian yang dilakukan oleh Totok Sunarko (2014), Ambarwati (2008) dan Nany (2003) menemukan bahwa return saham berpengaruh negatif signifikan terhadap bid-ask spread.

\section{Pengaruh Volume Perdagangan Terhadap Bid Ask Spread}

Berdasarkan analisis regresi data panel yang telah dilakukan, variabel volume pedagangan saham memiliki t-statistic -49.72973 lebih kecil dari t kritis (tabel) yaitu 1.960 dan p-value pada variabel volume perdagangan saham sebesar 0.0000 lebih kecil dari $a=0.05(5 \%)$ sehingga volume perdagangan saham memiliki pengaruh signifikan terhadap bid ask spread.

Volume perdagangan merupakan suatu instrumen yang dapat digunakan untuk melihat reaksi pasar modal terhadap informasi melalui parameter pergerakan aktivitas volume perdagangan di pasar. Volume perdagangan saham yang besar menandakan bahwa saham tersebut aktif ditransaksikan sehingga broker atau dealer tidak perlu menyimpan saham terlalu lama sehingga menurunkan biaya pemilikan saham tersebut yang berdampak pada bid-ask spread yang lebih sempit. Perdagangan saham yang aktif yaitu dengan volume perdagangan yang besar, yang menunjukkan bahwa saham tersebut digemari investor, berarti bahwa saham tersebut cepat diperdagangkan. Kondisi tersebut menyebabkan trader tidak perlu terlalu lama memegang saham, yang mengakibatkan penurunan biaya kepemilikan saham. Semakin cepat perdagangan suatu saham semakin besar volume saham diperdagangkan yang mengakibatkan penurunan biaya kepemilikan saham. Menurunnya biaya kepemilikan saham berarti akan mempersempit bid-ask spread saham tersebut. Hasil penelitian ini sesuai dengan penelitian yang dilakukan oleh Lulu Nurul Istanti (2009), Sri Dwi Ari Ambarwati (2008), yang menyatakan bahwa voluem perdagangan saham berpengaruh negatif signifikan terhadap bid ask spread.

\section{Pengaruh Risiko Return Saham Terhadap Bid Ask Spread}

Berdasarkan analisis regresi data panel yang telah dilakukan, variabel risiko return saham memiliki t-statistic -44.11019 lebih kecil dari t kritis (tabel) yaitu 1.960 dan p-value pada variabel risiko return saham sebesar 0.0000 lebih kecil dari $\alpha=0.05(5 \%)$ sehingga risiko return saham memiliki pengaruh signifikan terhadap bid ask spread.

Risiko dalam investasi saham biasa juga harus dipertimbangkan oleh investor. Return dan risiko mempunyai hubungan yang positif, semakin besar risiko yang harus ditanggung, semakin besar return yang harus dikompensasikan. Risiko merupakan besarnya penyimpangan antara tingkat pengembalian yang diiharapkan (expected return) dengan tingkat pengembalian yang dicapai secara nyata (actual return). Semakin besar penyimpangan berarti semakin besar tingkat risikonya. Risk of return merupakan tingkat risiko yang terjadi dari suatu kegiatan investasi akibat transaksi saham di pasar bursa yang 
dicerminkan dari standar deviasi yang digunakan untuk mengetahui seberapa jauh kemungkinan nilai yang menyimpang dari nilai yang diharapkan.

Berdasarkan hasil penelitian diperoleh hasil yang menunjukkan bahwa selama periode penelitian variabel risk of return mempunyai pengaruh yang signifikan terhadap bid-ask spread. Yang berarti semakin besar risiko yang harus ditanggung, semakin besar return yang harus dikompensasikan. Semakin tinggi volatilitas return saham maka semakin tinggi pula nilai spread relatif saham. Hasil penelitian ini sesuai dengan penelitian yang dilakukan oleh Lulu Nurul Istanti (2009), yang menyatakan bahwa risiko return saham berpengaruh negatif signifikan terhadap bid ask spread.

\section{Penutup dan Saran}

Berdasarkan analisis regresi data panel harga saham, return saham, volume perdagangan, dan risiko return saham terhadap bid ask spread menggunakan studi data harian perusahaan yang terdaftar di LQ45 tahun 2019, diperoleh kesimpulan sebagai berikut:

1. Harga saham memiliki pengaruh positif signifikan terhadap bid ask spread. Hal ini mengindikasi bahwa saham tersebut digemari oleh para investor. Keadaan ini juga senantiasa membuat dealer tidak langsung melepas saham tetapi saham tersebut ditahan terlebih dahulu sampai pada waktu tertentu, sehingga semakin lama saham tersebut berada di tangan dealer maka menimbulkan lebih besarnya bid ask spread.

2. Return saham memiliki tidak berpengaruh terhadap bid ask spread. Hal ini menunjukkan bahwa saham tersebut aktif dalam perdagangan. Dealer sebagai pihak penghubung akan menurunkan biaya karena tidak menahan saham dalam waktu yang cukup lama dan akan menurunkan bid-ask spread (Ambarwati, 2008). Return yang tinggi mengindikasikan bahwa saham tersebut aktif diperdagangkan. Dengan demikian biaya untuk kepemilikan pada akhirnya akan menurun.

3. Volume perdagangan saham memiliki pengaruh negatif signifikan terhadap bid ask spread. Perdagangan saham yang aktif yaitu dengan volume perdagangan yang besar, yang menunjukkan bahwa saham tersebut digemari investor, berarti bahwa saham tersebut cepat diperdagangkan. Kondisi tersebut menyebabkan dealer tidak perlu memegang saham terlalu lama, yang mengakibatkan menurunnya biaya kepemilikan saham, semakin cepat perdagangan suatu saham semakin besar volume saham yang diperdagangankan sehingga mengakibatkan penurunan biaya kepemilikan saham.

4. Risiko return saham memiliki pengaruh negatif signifikan terhadap bid ask spread. Risiko dalam investasi saham biasa juga harus dipertimbangkan oleh investor. Risiko return saham sangat mempengaruhi keputusan investor dalam pengambilan keputusannya. Hal tersebut dikarenakan semakin besar risiko yang harus ditanggung, semakin besar return yang harus dikompensasikan. Semakin tinggi volatilitas return saham maka semakin tinggi pula nilai spread relatif saham.

5. Harga saham, return saham, volume perdagangan, dan risiko return saham memiliki pengaruh signifikan terhadap bid ask spread. Menurut signaling theory keputusan dalam menjual dan membeli saham didasari oleh data-data harga dan volume perdagangan di masa lalu. Informasi data masa lalu tersebut akan mendasari prediksi mereka atas pola perilaku harga saham di masa datang yang dapat menghasilkan return tinggi. Untuk mendapatkan return yang tinggi, maka seorang investor harus mampu mendapatkan informasi lebih cepat dibanding investor lain, karena penyerapan informasi seperti ini disebabkan karena adanya informasi yang tidak simetris, sehingga menyebabkan tingkat spread tinggi. 
6. Penelitian ini menggambarkan perilaku investor harian yang memiliki biaya asimetris yang kecil sehingga saham perusahaan indeks LQ45 lebih condong/masuk ke dalam kategori saham yang sering ditransaksikan dibandingkan dengan kategori saham yang memiliki kondisi keuangan baik yang mendorong bid ask spread yang lebih besar.

\section{Referensi}

Ambarwati, S. D. A. (2008). Pengaruh Return Saham, Volume Perdagangan Saham Dan Varian Return Saham Terhadap Bid Ask Spread Saham Pada Perusahaan Manufaktur Yang Tergabung Dalam Indeks Lq 45 Periode Tahun 2003-2005. Jurnal Siasat Bisnis, 12(1), 27-38.

Aprilia, Z. (2015). Faktor-Faktor yang Mempengaruhi Bid-Ask Spread Saham LQ-45 di Bursa Efek Indonesia. Jurnal Riset Ekonomi dan Manajemen, 15(2), 396-407.

Fitriyah, F. (2012). Implikasi Market Value, Varian Return, Laba per Saham dan Deviden Terhadap Bid-Ask Spread Saham Syariah. Iqtishoduna.

Halim, A., \& Hidayat, N. (2000). Studi Empiris Tentang Pengaruh Volume Perdagangan dan Return Terhadap Bid-ask Spread Saham Industri Rokok di Bursa Efek Jakarta Dengan Model Koreksi Kesalahan. The Indonesian Journal of Accounting Research, 3(1), 69-85.

Istanti, L. N. (2009). Pengaruh Harga Saham, Trading Volume Activity dan Risiko Saham Terhadap Bid-Ask Spread (Studi pada Perusahaan LQ-45 di Bursa Efek Jakarta). Jurnal Ekonomi Modernisasi, 5(3), 199-210.

Nany, M. (2003). Analisis Pengaruh Harga Saham, Return Saham, Varian Return Saham, Earnings dan Volume Perdagangan Saham Terhadap Bid Ask Spread sebelum dan Sesudah Pengumuman Laporan Keuangan (Studi Empiris Pada Saham LQ45 Di Bursa Efek Jakarta). Jurnal Perspektif, 9(1): 23-31.

Purwanto, A. (2004). Pengaruh Harga Saham, Volume Perdagangan, Dan Varian Return Terhadap Bid-Ask Spread Pada Masa Sebelum Dan Sesudah Right Issue Di Bursa Efek Jakarta Periode 2000-2002. Jurnal Akuntansi Dan Auditing (JAA), 1(Nomor 1), 66-82. 